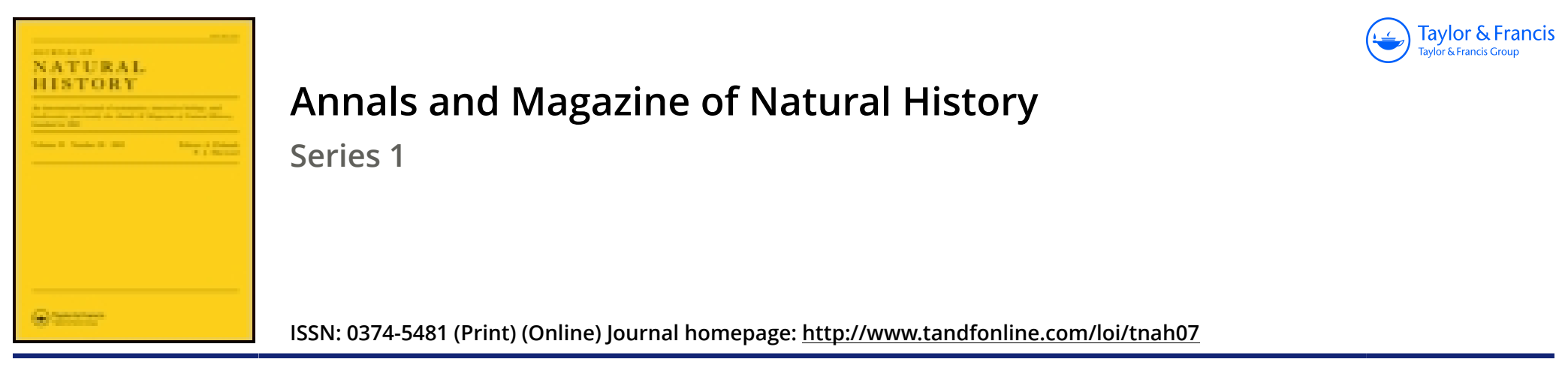

\title{
XLIV.-Observations on the Gasteropod Mollusca, designated by the name of Phlebenterata by M. de Quatrefages
}

\section{Souleyet}

To cite this article: M. Souleyet (1844) XLIV.-Observations on the Gasteropod Mollusca, designated by the name of Phlebenterata by M. de Quatrefages, Annals and Magazine of Natural History, 14:92, 342-348, DOI: 10.1080/037454809495190

To link to this article: http://dx.doi.org/10.1080/037454809495190

曲 Published online: 16 Dec 2009.

Submit your article to this journal $\pi$

Џll Article views: 2

Q View related articles $\sqsubset$ 
prothorax very short: scutum of the mesothorax broad; sutures of the parapsides indistinct; axillæ large, triangular ; scutellum rhomboidal : metathorax very short: propodeon short, decumbent : po.deon very short: abdomen circular, smooth, shining, concave, a little broader and much shorter than the thorax, having a fulvous spot towards the base; metapodeon large; octoon and the following segments short: legs yellow; coxæ green : wings having a slight fulvous tinge; nervures fulvous; humerus much less than half the length of the wing; ulna more than half the length of the humerus; radius not longer than the ulna; cubitus hardly more than half the length of the ulna; stigma small, emitting a very short branch.

Alten.

XLIV.-Observations on the Gasteropod Mollusca, designated by the name of Phlebenterata by $M$. de Quatrefages. By $M$. SOULEYET*.

M. DE Quatrefages has communicated to the Academy of Sciences a series of researches upon a group of Gasteropod Mollusca, whose organization differs widely, according to that naturalist, from that of the animals of the same type, and presents very singular peculiarities. M. de Quatrefages says, in fact, that he has observed in these Mollusca the partial or complete disappearance of the organs of circulation, whence would result a corresponding degradation in the respiratory organs; and he is moreover very much inclined to the opinion that the posterior aperture of the digestive tube disappears even in some of these Gasteropods, which would consequently bring them much nearer to animals of the most simple structure-the Medusa for example.

The strangeness of these results, which appear to me contrary not only to all known facts on the organization of Mollusca, but also to all admitted and recognised principles in zoology, led me to extend the researches which I made some years ago on the anatomy and physiology of these animals, to those which form the subject of the memoirs published by M. de Quatrefages. Having already had occasion to observe some of these Gasteropods during the expedition round the world of the Bonite, I endeavoured to complete this investigation by that of species which are found on our coasts; but, as I cannot yet submit to the Academy the work which I have written on this subject, and which is retarded by the execution of the drawings accompanying it, I meantime request permission to state succinctly some of the results at which I have arrived, and which appear to me to contradict almost entirely those announced by $\vec{M}$. de Quatrefages.

It is known that among the Mollusca in question there are first

* From the Comptes Rendus for August 12th, 1844. 
the Eolides and some other closely allied genera*, Cavolina, Tergipes, Calliopaa, Glaucus, \&c., genera which often differ only in external characters of little importance, and which certainly form in the class of Gasteropoda one of the most natural families. However, according to the observations of M. de Quatrefages, these mollusca present in their internal structure the greatest differences: thus the Eolides have a heart and arteries, without a venous system, and in the other genera of the same group which this naturalist examined, there no longer existed any trace of the circulatory apparatus. I have observed Cavolina, Calliopcea, Glaucus, Tergipes (a genus which appears to me to have the nearest relation to the genus Amphorina proposed by M. de Quatrefages), as well as a mollusk which presented the characters assigned by Messrs. Alder and Hancock to their genus Venilia, to which M. de Quatrefages has himself referred his genus Zephyrina, and I can affirm that all these mollusca have a heart and an arterial system, disposed as in the Eolides. It is not very difficult to ascertain the existence of these organs, provided we do not investigate these animals solely as transparent objects.

I have stated, that even if $M$. de Quatrefages admits the existence of a heart and arterial system in some of these mollusca, it is not the same with the venous system which he says explicitly is wanting in all; and as it was nevertheless necessary to explain, in the Eolides, the return of the blood towards the circulatory centre, this naturalist supposes that this fluid, after having traversed the arteries, is distributed in the general cavity of the body, whence the contractions of the animal propel it in successive waves to the ventricle. Admitting even this theory as probable, the following anatomical fact, easy of verification in the large species of Eolis, appears to me to destroy it completely. If, after having opened carefully the pericardium, we inject the auricle by the ventricle (an experiment which $I$ have several times performed on the Eolis Cuvierii, common on the coasts of the British Channel) and propel the liquid slowly, we soon see this

* I do not think we can enumerate among these genera, Eolidina, which differ from the Eolides, according to M. de Quatrefages, by the absence of labial tentacles, these tentacles not existing in any of the known species of the genus Eolis. Some authors, from examining individuals contracted by alcolicl, have taken for tentacular prolongations, the lateral points formed by the anterior margin of the foot, and have thus assigned three pairs of tentacles to these mollusea; but this error has been already noticed by everal naturalists.

Some other genera of this group, as Cavalina, Amphorina, Zephyrina, $\& c$., do not rest equally upon cliaracters sufficiently important or well-ascertained for us to adopt them; but I cannot here enter into a discussion of this subject. 
liquid swell the auricle and at length penetrate into the thickness of the tissues of the external envelope, forming currents which it is possible to follow as far as the branchial appendices; I have never seen the injected liquid spread itself into the visceral cavity. It is also possible, by a very attentive examination, to recognise the small venous vessels which, from the viscera and especially from the ovary, proceed into the external envelope. But I must also recall the fact, that in most of the Mollusca, the venous system is much less apparent than the arterial system, and that it often happens, as M. de Blainville has pointed out in his 'Traite de Malacologie,' that the sides of the venous vessels, already extremely thin, are moreover so blended with the tissue of the parts, that it becomes very difficult to recognise them : most commonly then these venous vessels only assume a very distinct vascular appearance in the large trunks which go to the respiratory organs, when the latter are very circumscribed; but if these organs do not present this last character, as is the case evidently in the Eolides, the venous system will necessarily present an analogous diffusion. Facts therefore appear to me to agree with reasoning and with analogy, to prove that the venous system really exists in the Eolides and in all the other mollusca of the same group.

The details into which I have entered, and those in addition which it will be possible for me to give on the structure of the external appendices of these mollusca, will also show, I hope, that these appendices perform really the respiratory functions.

M. de Quatrefages thinks he has discovered the reason of the degradation of the organs of circulation and respiration in the Mollusca Phlebenterata in an anatomical peculiarity first observed by MM. Milne Edwards and Lowèn in Calliopaa and Eolis, and which consists in a prolongation of the digestive cavity in the appendices of the branchix. That naturalist is of opinion that this disposition of the digestive tube has the object of supplying the absence of the organs of respiration, by permitting the direct action of the air on the nutritive matters.

The following facts and arguments appear to me again wholly to contradict this theory:-

1. If such were really the object assigned by nature to that organic disposition, there ought evidently to be a relation between the progressive degradation of the organs of respiration and circulation and the development of those ramifications of the digestive cavity which should supply their functions : now precisely the contrary takes place. Thus the Eolides, which, according to M. de Quatrefages himself, still possess a circulation and numerous branchial appendices, have also a very ramified digestive tube; and the last genera of his order which he designates under 
the names of Pelta and Chalidis, which possess neither circulation nor respiratory appendices, do likewise not present any trace of these ramifications of the digestive cavity.

2. If we study the internal structure of the branchial appen dices in all these mollusca, we see that the prolongations of the digestive cavity which traverse the centre are always separated from the dermoidal envelope (as is represented in the drawings of M. de Quatrefages) by a layer more or less thick, according to the size of these appendices, of a granulous brownish or yellowish substance, which that naturalist has considered to be the liver; - a conclusion which I completely adopt, because it seems to me really impossible to give a different one. We must then admit that the oxygenation of the nutritive matters would be through this organ, and that nature, which in the construction of the parts destined to the function of respiration has always sought to bring as near as possible the external fluid with the liquid upon which it has to act, would have here followed quite a contrary rule.

3. Admitting that this action of the air was still possible, notwithstanding what $I$ have just said, it would yet be necessary to explain, how the nutritive fluid, after having undergone it, could be carried into the different parts of the body, in animals which present no trace of organs of circulation.

4. If we are not preoccupied with the idea of finding in the organization of these animals an organic combination which takes the place of the apparatus of respiration and circulation, since these apparatus exist according to my observations, we may give a much more natural explanation of this ramified disposition of the digestive tube in the Eolidina. In fact, as I have already said, these ramifications terminate in the liver, and as I shall easily make clear, the trunks which furnish them always open into the stomachal pouch, it seems to me to follow naturally that these ramified canals are biliary ducts; thus we find them almost always filled with a thick and brownish matter having all the appearance of bile. This gastro-biliary apparatus (a denomination which appears to me more suitable than that of gastro-vascular) differs from the same apparatus in most of the other mollusca only in the fact that the biliary vessels, instead of uniting successively to form a single trunk, form on each side a series of canals which open detached in the stomachal pouch, and it is easy to detect the connexion which exists between this disposition and the kind of diffusion which, so to speak, the liver presents in all the appendices which cover the back of the animal. In another mol-. lusk, on the analogies of which zoologists are still very uncertain,
Ann.\& Mag. N. Hist. Vol. xiv.
$2 \mathrm{~A}$ 
but which, it seems to me, in many relations, must be placed by the side of the Eolides, Phylliroe, the liver occurs in the form of cæca which open detached into the stomachal cavity, and thus presents a disposition which leads to that which is observed in all the mollusca of the family of the Eolides; only that, in these last, the cæca of the liver, instead of remaining internal, become external, propelling, so to speak, the skin before them,--a remarkable and wholly exceptional peculiarity, which belongs perhaps to some biological circumstances in these mollusca.

In his last communication to the Academy, M. de Quatrefages has expressed the opinion that this division of the liver was necessitated by the ramified disposition of the digestive cavity; but this necessity is not very evident, and, according to what I have said above, this position of the liver around ramifications of the stomach is, on the contrary, wholly in contradiction to the functions which that naturalist assigns to them.

I have already said that this gastro-biliary apparatus always opens into the stomachal cavity, and in fact M. de Quatrefages is wrong in making it terminate thus in the intestine or in the buccal cavity. As I cannot enter here into details on this subject, I shall only remark that, in all these mollusea, the intestine properly so called has escaped the researches of this naturalist; this has caused him to assign a false position to the anus, or has led him to mistake the existence of that aperture*.

In the statement which I have just given of the result of my researches on the Eolides and the other genera which belong to the same group, I have mentioned only what appeared to me to have a reference to the general questions raised by M. de Quatrefages; but I should observe, that on several other points my observations disagree with those of that naturalist, and especially on the organs of generation, whose conformation appears to me not at all to resemble the description which he has given of them : I shall show in fact that this apparatus is wholly analogous to that of the other Nudibranch Mollusca, and especially of the Tritonice.

Amongst the other genera of Mollusca which M. de Quatrefages has arranged after the Eolidians, in his order Phlebenterata, is Oken's Acteon, and which is identical, as I have assured myself, with the genus described by M. Risso under the name Elysia. The observations which I have made on this small mollusk are quite opposed to those of M. de Quatrefages, who moreover

- The deseription which M. de Quatrefages has given of the gastro-biliary apparatus in the Eolidina is wholly inexact; the canals which lead from the stomachai cavity never terminate in lateral trunks, as is represented in the figure given by that naturalist. 
has given only a very insufficient description; I can however only indicate here briefly the errors which he appears to me to have committed.

1. Contrary to the assertions of this naturalist, the Acteon has a heart, an arterial system, \&c.; in a word, a complete apparatus of circulation which has much analogy with that of the Eolides.

2. The dorsal pouch which M. de Quatrefages has considered as the stomach, and from which proceed the ramified canals which cover, above, the lateral expansions of the animal, has no communication with the digestive tube; it is a distinct apparatus which opens externally by a peculiar orifice placed behind that of the anus, and which seems to serve for the respiration in this mollusk. In the same way the ramifications of this apparatus have no communication with the vesiculous ampulliform organs, which thus in no way present the regular position which this naturalist assigns to them in his figures.

3 . The whole digestive tube, from the buccal cavity, the description of which likewise differs from my investigations, appears to have escaped the observation of M. de Quatrefages.

4. The position which M. de Quatrefages assigns to the anus, at the posterior and median portion of the body, is certainly inaccurate; there is at that point neither orifice nor cloacum. The anal aperture is situated at the anterior and dorsal part of the animal on the right side, and always occurs in the form of a small protuberance, which is easy of detection.

5 . The genital orifice is not simple, and has likewise a different position to that which M. de Quatrefages assigns to it; the aperture of the oviduct is on the right side, in a small groove which descends from the anus towards the lower surface of the animal; that of the male organ is situated on the same side, at the base of the tentacle.

My observations on the zoological characters of Acteon agree entirely with those which have been communicated to me by $\mathbf{M}$. Vérany of Genoa, who has often had opportunities of observing this small mollusk.

M. de Quatrefages has given no detail on the reproductive apparatus of Acteon; but he appears to say that the arrangement of that apparatus is the same as that which he indicates in a succinct manner in his genus Acteonia : in that case, I might still affirm that the organs of generation in Acteon have no analogy with the description which is given by that naturalist.

I can say nothing of the genera Acteonia, Placobranchus, Pelta and Chalidis, which are also included in the order of the Phlebenterate Mollusca of M. de Quatrefages, not having been able as yet to procure these mollusca. But of these genera, the first or Acteonia does not differ from Acteon, according to this 
naturalist himself, who moreover has given no other detail respecting its internal organization than the short description of the generative apparatus which I have already noticed. It is then a genus concerning which nothing can be determined. The genus Placobranchus, established by Van Hasselt, has been referred to this order solely from the analogy which it presents with the genus Acteon. The last two genera, Pelta and Chalidis, then remain, on the subject of which it is impossible for me to oppose my observations to those of M. de Quatrefages*. If however we consider the numerous errors of observation which I have pointed out in the investigations of that naturalist, and the proofs of which it will be easy for me to furnish,-if moreover we admit that these errors may have been more easy to commit on animals which are almost microscopical, it will follow, I think, that the facts which M. de Quatrefages has enumerated in the organization of these mollusca do not present a degree of certainty sufficient to be accepted in sound zoology,-these facts being in contradiction to all other received facts and to all analogy.

In replying to the assertions of $M$. de Quatrefages in this short notice, I have had occasion sometimes to argue upon facts which do not appear to me to have received the most rational explanation, and every one may consequently appreciate the value and justness of my arguments ; but most frequently I have found that I disagreed with the facts themselves, and have then been obliged to question their accuracy. I am aware that it remains for me to oppose facts to them; but these proofs, which I have in $\mathrm{my}$ possession, I shall submit together with my work to the Academy, and they will, I hope, place beyond a doubt all that I have advanced and all that I have objected to.

XLV._On Thalassidroma melitensis, Schembri, a supposed new species of Stormy Petrel. By H. E. Strickxand, M.A.

In the valuable paper on the birds of the Ionian Islands by Capt. H. M. Drummond (Annals of Nat. Hist. vol. xii. p. 422), that gentleman remarks that the bird which he had considered to be Thalassidroma pelagica was more probably the $T$. melitensis, a new species discovered at Malta by Sigr. Schembri, and supposed to be peculiar to the Mediterranean. In the excellent little work of the last-named author, entitled 'Catalogo Ornitologico del Gruppo di Malta,' published in 1843, is a description and figure of the Thalassidroma melitensis, the distinctive characters of which

- I have not been able to examine the objects collected and described by M. de Quatrefages, that naturalist not having deposited them in the galleries of the Museum. 